\title{
BIOMASSA SESAAT SUMBER DAYA PERIKANAN UNDUR-UNDUR LAUT (CRUSTACEA: DECAPODA: HIPPIDAE) DI PANTAI BERPASIR CILACAP DAN KEBUMEN, JAWA TENGAH
}

\author{
Momentarily Biomass of Mole Crab Resources (Crustacea: Decapoda: Hippidae) in Cilacap \\ and Kebumen Sandy Beaches, Central Java \\ Oleh: \\ Ali Mahsar ${ }^{1 *}$ dan Yusli Wardiatno ${ }^{1}$ \\ ${ }^{1}$ Departemen Manajemen Sumberdaya Perairan, Fakultas Perikanan dan Ilmu Kelautan, Institut Pertanian Bogor \\ *Korespondensi: alimashar75@gmail.com
}

Diterima: 6 April 2016; Disetujui: 26 Oktober 2016

\begin{abstract}
Mole crab is a benthic animal that live buried in sandy beach in the intertidal area. Mole crab has an important ecological role and also has economic value. The sandy beach in south of Cilacap and Kebumen is mole crab's habitat. Mole crab exploitation in these areas has been increasing for consumption demand. To determine the significant role of the mole crab in the provision of nutritious food, it is necessary to estimate the potential of mole crab biomass. This study aims to determine standing biomass of the mole crab in Kebumen and Cilacap sandy beaches. The specimen collection was conducted by sampling methods every month in March 2012 to February 2013 on Bocor beach, Kebumen and June 2013 to May 2014 on Bunton beach, Cilacap. The data processing was conducted by descriptive statistics methods. The results showed that standing biomass of mole crab family Hippidae, namely Emerita emeritus and Hippa adactyla, fluctuated between 102 and $508 \mathrm{~kg}$ on the Kebumen sandy beach, and between 1,811 and 4,671 $\mathrm{kg}$ on the Cilacap sandy beach. Standing biomass of E. emeritus fluctuated between 82 and $497 \mathrm{~kg}$ on the Kebumen sandy beach and between 1,462 and $3,560 \mathrm{~kg}$ on the Cilacap sandy beach. Standing biomass of $\mathrm{H}$. adactyla fluctuated between 2 and $133 \mathrm{~kg}$ on the Kebumen sandy beach, and between 234 and $1,701 \mathrm{~kg}$ on the Cilacap sandy beach. The difference in standing biomass in each location was caused by the difference of sampling time and environment condition of research area. The economic value potential of the mole crab as fishery resources is discussed.
\end{abstract}

Keywords: Emerita emeritus, Hippa adactyla, Hippidae, momentarily biomass,

\section{ABSTRAK}

Undur-undur laut adalah kelompok hewan bentik yang hidup mengubur di daerah intertidal bersusbtrat pasir. Undur-undur laut mempunyai peran ekologis penting dan juga bernilai ekonomis. Pantai berpasir selatan Cilacap dan Kebumen adalah habitat undur-undur laut. Penangkapan undur-undur laut di kedua wilayah tersebut makin meningkat untuk kebutuhan konsumsi. Untuk mengetahui peran undur-undur laut dalam mendukung penyediaan bahan pangan bergizi, perlu diketahui potensi biomassa undur-undur laut. Penelitian ini bertujuan untuk mengetahui biomassa sesaat undur-undur laut dan fluktuasinya di pantai berpasir Kabupaten Kebumen dan Cilacap. Pengumpulan spesimen undur-undur laut dilakukan dengan metode sampling setiap bulan pada Maret 2012 hingga Februari 2013 di pantai Bocor Kebumen dan pada Juni 2013 hingga Mei 2014 di pantai Bunton Cilacap. Pengolahan data dilakukan dengan metode statistik deskriptif. Hasil penelitian menunjukkan bahwa besaran biomassa sesaat (standing biomass) undur-undur laut famili Hippidae, yaitu Emerita emeritus dan Hippa adactyla, berfluktuasi antara $102 \mathrm{~kg}$ hingga 508 
$\mathrm{kg}$ di pantai berpasir Kebumen, dan antara $1.811 \mathrm{~kg}$ hingga $4.671 \mathrm{~kg}$ di pantai berpasir Cilacap. Standing biomass E. emeritus berfluktuasi antara $82 \mathrm{~kg}$ hingga $497 \mathrm{~kg}$ di pantai berpasir Kebumen dan antara $1.462 \mathrm{~kg}$ hingga $3.560 \mathrm{~kg}$ di pantai berpasir Cilacap. Standing biomass $\mathrm{H}$. adactyla berkisar antara $2 \mathrm{~kg}$ hingga $133 \mathrm{~kg}$ di pantai berpasir Kebumen, dan antara $234 \mathrm{~kg}$ hingga $1.701 \mathrm{~kg}$ di pantai berpasir Cilacap. Perbedaan besaran standing biomass di masing-masing lokasi dipengaruhi oleh perbedaan waktu pengumpulan data undur-undur laut dan perbedaan kondisi lingkungan lokasi penelitian. Potensi ekonomi sebagai sumber daya perikanan undur-undur laut juga dibahas dalam paper ini.

Kata kunci: Emerita emeritus, Hippa adactyla, Hippidae, biomassa sesaat

\section{PENDAHULUAN}

Undur-undur laut adalah hewan bentik yang hidup di daerah intertidal pantai berpasir (Efford 1976; Haley 1982; Mashar et al. 2014). Undur-undur laut banyak dijumpai di pantai berpasir wilayah Indonesia, terutama wilayah pantai barat Sumatera dan pantai selatan Jawa (Boyko dan Harvey 1999; Boyko 2002; Haye et al. 2002). Di antara wilayah-wilayah pantai di Indonesia tersebut, undur-undur laut banyak dijumpai di pantai Kebumen dan Cilacap, Jawa Tengah, dan di kedua lokasi dikenal dengan nama lokal "yutuk"dan merupakan target tangkapan nelayan perikanan pada wilayah intertidal (Mashar dan Wardiatno 2013ab; Mashar et al. 2014; Wardiatno et al. 2014; Osawa et al. 2010). Undur-undur laut famili Hippidae yang ditemukan di pantai Kebumen dan Cilacap terdiri dari dua jenis, yaitu Emerita emeritus dan Hippa adactyla. Selain dari famili Hippidae, ternyata di kedua pantai tersebut juga dijumpai satu jenis undur-undur laut lain dari famili Albuneidae, yaitu Albunea symmysta. Secara umum, populasi dan kelimpahan undurundur laut dari famili Hippidae di kedua lokasi tersebut jauh lebih tinggi dari famili Albuneidae (Mashar et al. 2014).

Undur-undur laut memiliki peran ekologis cukup penting di habitatnya, terutama dalam rantai makanan di daerah intertidal. Undurundur laut berperan sebagai konsumen tingkat pertama dan produsen bagi konsumen tingkat kedua (Siegel dan Wenner 1984). Selain peran ekologis, undur-undur laut juga memiliki nilai gizi cukup tinggi, terutama protein, omega-3, dan omega-6. Hartono et al. (2011) melaporkan bahwa undur-undur laut mempunyai kandungan protein $32,32 \%$ dan omega-3 $12,49 \%$. Santoso et al. (2015) melaporkan kandungan protein undur-undur laut sekitar 38,5\% bobot kering. Adapun Mursyidin (2007) melaporkan bahwa kandungan omega- 6 pada undur-undur laut sebesar 11,80\%-12,94\%. Dengan demikian, undur-undur laut cukup baik untuk dikonsumsi, terutama bagi pertumbuhan dan perkembangan otak anak-anak.

Kandungan gizi undur-undur laut yang cukup tinggi tersebut mengindikasikan bahwa undur-undur laut dapat memiliki peran cukup potensial dalam ketahanan pangan nasional. Undur-undur laut dapat digunakan sebagai salah satu sumber bahan pangan bergizi bagi masyarakat, terutama bagi anak-anak yang masih dalam masa pertumbuhan, baik dengan dimanfaatkan secara langsung maupun diolah terlebih dahulu. Untuk mengetahui seberapa besar peran undur-undur laut dalam menyediakan sumber pangan bergizi bagi masyarakat, maka perlu diketahui potensi biomassa undurundur laut. Salah satu bentuk biomassa yang dapat menggambarkan kondisi biomassa total dari suatu wilayah tertentu pada saat penelitian adalah biomassa sesaat (standing biomass). Pada penelitian sebelumnya telah diteliti tentang sebaran komposisi dan kelimpahan undurudur laut di pantai Cilacap dan Kebumen (Mashar et al. 2014). Namun penelitian tentang biomassa dan bioamssa sesaat belum pernah dilakukan sebelumnya di Indonesia. Oleh karena itu, penelitian kondisi biomassa sesesaat undur-undur laut ini perlu dilakukan di pantai Cilacap dan Kebumen sebagai langkah awal untuk mengetahui potensi undur-undur laut dalam menyediakan salah satu sumber pangan bergizi. Penelitian ini bertujuan untuk mengetahui potensi biomassa sesaat sumber daya perikanan undur-undur laut famili Hippidae sebagai sumber daya perikanan di pantai berpasir Kabupaten Kebumen dan Kabupaten Cilacap, Jawa Tengah.

\section{METODE}

Penelitian ini dilakukan di pantai Bocor, Kecamatan Buluspesantren, Kabupaten Kebumen $\left(7^{\circ} 47^{\prime} 33,7^{\prime \prime}\right.$ LS dan 109'40'00,9" BT hingga $7^{\circ} 47^{\prime} 54,8^{\prime \prime}$ LS dan 109 $41^{\prime} 36,4^{\prime \prime}$ BT) dan pantai Bunton, Kecamatan Adipala, Kabupaten Cilacap $\left(7^{\circ} 41^{\prime} 26,6^{\prime \prime}\right.$ LS dan $109^{\circ} 09^{\prime} 30,7^{\prime \prime}$ BT hingga $7^{\circ} 41^{\prime} 25,2^{\prime \prime}$ LS dan $109^{\circ} 09^{\prime} 17,3^{\prime \prime}$ BT) (Gambar 1). Pengumpulan sampel undur-undur laut dilakukan setiap bulan selama satu tahun. Pengumpulan sampel undur-undur laut di pantai Bocor, Kebumen, dilakukan dari bulan Maret 2012 hingga Februari 2013, sedangkan pengumpulan sampel di pantai Bunton, Cilacap, dilakukan dari bulan Juni 2013 hingga Mei 2014. 


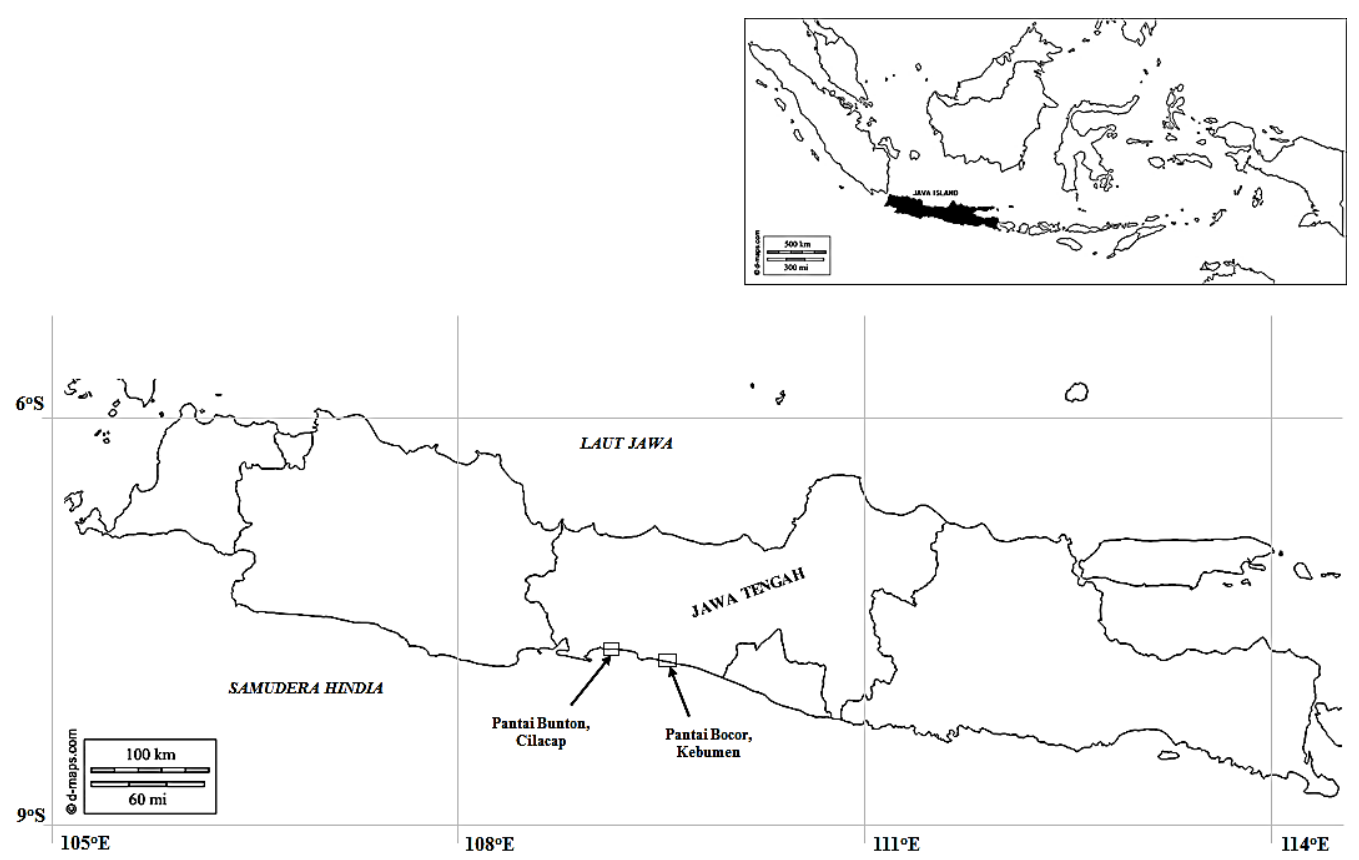

Gambar 1 Lokasi pengambilan sampel undur-undur laut (Sumber peta: www.d-maps.com/asia/ indonesia/central java)

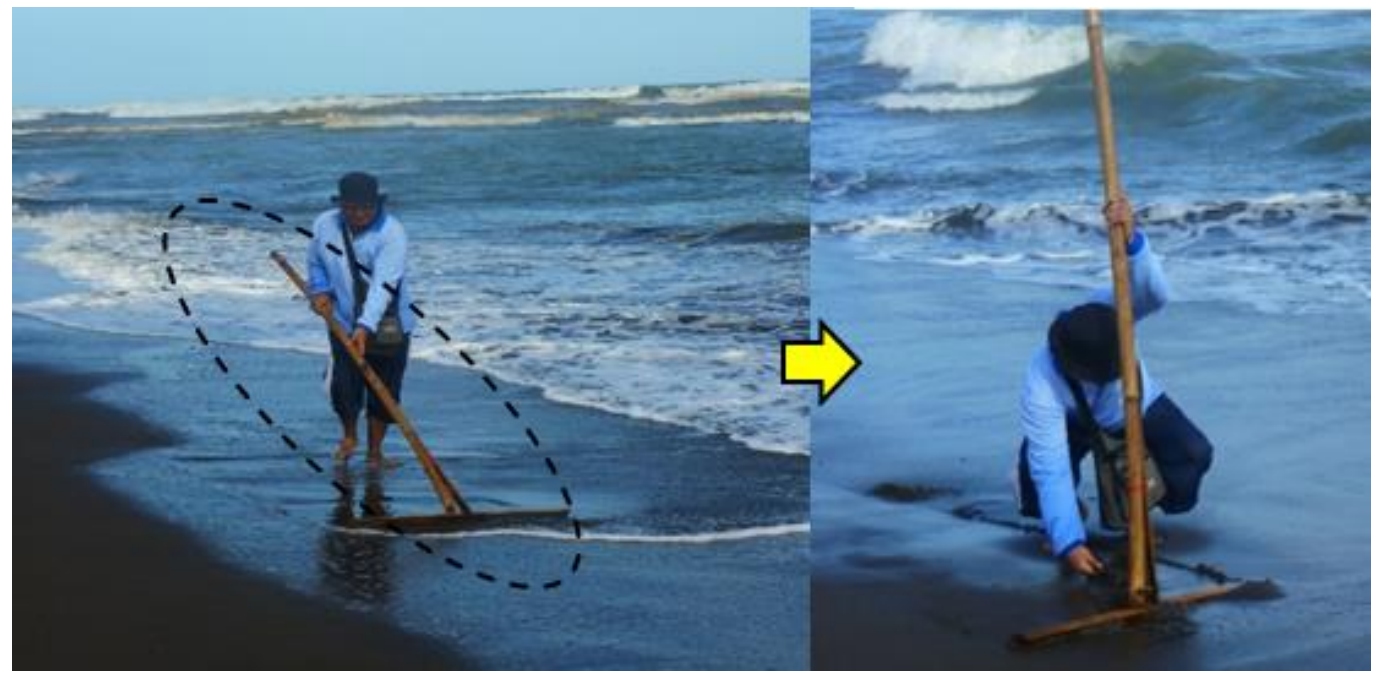

Gambar 2 Deskripsi alat tangkap “sorok” untuk mendeteksi keberadaan undur-undur laut

Seluruh undur-undur laut yang tertangkap, kemudian dimasukkan ke dalam botol sampel dan dipisahkan per jenis undur-undur laut. Kemudian undur-undur laut dalam setiap botol sampel direndam dengan alkohol 10\%, setelah direndam sehari, alkohol tersebut diganti seluruhnya dengan alkohol 96\%. Kemudian sampel undur-undur laut dibawa ke laboratorium untuk ditimbang bobotnya dan diukur panjang karapasnya.

Data sampel undur-undur laut yang telah terkumpul kemudian diolah dengan metode statistik deskriptif. Data biologis undur-undur laut diolah untuk menentukan berat rata-ratadan rata-rata luas area tangkapan. Adapun untuk data kelimpahan diambil dari hasil penelitian Mashar et al. (2014). Untuk mengetahui perkembangan harga jual undur-undur laut, dilakukan wawancara tidak terstrutktur dengan nelayan dan pedagang undur-undur laut.

Analisis data pada penelitian adalah penghitungan status biomassa sesaat (standing biomass) undur-undur laut, yang secara sederhana ditulis dengan notasi matematika sebagai berikut:

$$
\begin{gathered}
S B=A \times \frac{N}{100} \times \frac{W}{1000} \\
A=L \times W_{b}
\end{gathered}
$$




$$
N=\left(\frac{n}{A_{s a}}\right) \times 100
$$

Dimana: $S B=$ standing biomass atau biomassa sesaat $(\mathrm{kg}) ; A=$ luas pantai lokasi penelitian $\left(\mathrm{m}^{2}\right) ; \mathrm{N}=$ kelimpahan rata-rata undurundur laut (ind. $/ 100 \mathrm{~m}^{2}$ ); W= berat rata-rata undur-undur laut (gr/ind.); $\mathrm{L}=$ panjang pantai lokasi penelitian $(\mathrm{m}) ; \mathrm{W}_{\mathrm{b}}=$ lebar pantai rata-rata di lokasi penelitian (m); $n=$ jumlah keseluruhan undur-undur laut yang tertangkap (ind.); dan $A_{s a}=$ luas area sapuan alat tangkap sorok $\left(\mathrm{m}^{2}\right)$. Luas pantai di setiap lokasi penelitian diukur sendiri selama penelitian dengan mengkalikan panjang pantai dengan lebar rata-rata pantai. Uji $t$ dengan $\alpha=0,05$ dilakukan untuk mengetahui perbedaan biomassa sesaat undurundur laut antarlokasi dan antarspesies.

\section{HASIL DAN PEMBAHASAN}

Undur-undur laut yang didapatkan selama penelitian fluktuatif tiap bulannya, yaitu berkisar antara 35 ekor hingga 263 ekor per bulan di pantai Bocor Kebumen, dan antara 317 ekor hingga 721 ekor per bulan di pantai Bunton Cilacap. Adapun total total undur-undur laut famili Hippidae yang terkumpul selama penelitian adalah 7.886 ekor, yaitu 1.440 ekor dari pantai Bocor, Kebumen, dan 6.446 ekor dari pantai Bunton, Cilacap. Kelimpahan undurundur laut famili Hippidae di pantai Bocor, Kebumen adalah sekitar 7 ind. $/ 100 \mathrm{~m}^{2}$, sedangkan di pantai Bunton, Cilacap adalah sekitar 44 ind./100 m² (Mashar et al. 2014).

Hasil perhitungan didapatkan bahwa rata-rata status biomassa sesaat (standing biomass) undur-undur laut famili Hippidae di pantai berpasir Kabupaten Kebumen adalah sebesar $286 \pm 134$ (SD) kg, sedangkan di pantai berpasir Kabupaten Cilacap adalah sebesar $3.225 \pm 870$ (SD) kg. Terlihat bahwa standing biomass undur-undur laut famili Hippidae yang terdapat di pantai Cilacap jauh lebih tinggi dari yang terdapat di pantai Kebumen. Secara ringkas, dinamika standing biomass undur-undur laut famili Hippidae di lokasi penelitian disajikan pada Gambar 3 dan Gambar 4.

Berdasarkan Gambar 3 dan 4 terlihat bahwa status biomassa sesaat (standing biomass) undur-undur laut famili Hippidae fluktuatif tiap bulannya, baik berdasarkan lokasi penelitian maupun berdasarkan jenis. Secara alamiah, fluktuasi standing biomass undurundur laut dapat terjadi karena adanya perbedaan populasi undur-undur laut antarlokasi dan antarjenis, yang di antaranya dapat disebabkan oleh faktor lingkungan, seperti suhu, salinitas, dan ketersediaan sumber makanan (Atar dan Secer 2003). Pada Gambar 3 terlihat bahwa di pantai Kebumen, standing biomass undur-undur laut gabungan tertinggi dijumpai pada bulan November sebesar $508 \mathrm{~kg}$, sedangkan terendah dijumpai pada bulan Desember sebesar $102 \mathrm{~kg}$. Berdasarkan jenis, standing biomass undur-undur laut Emerita emeritus cenderung selalu lebih tinggi dibanding Hippa adactyla. Standing biomass $E$. emeritus di pantai Kebumen berkisar antara $82 \mathrm{~kg}$ (November) hingga 497 $\mathrm{kg}$ (Oktober) dengan rata-rata $251 \pm 131$ (SD) $\mathrm{kg}$, sedangkan untuk $H$. adactyla berkisar antara $2 \mathrm{~kg}$ (Juli) hingga $133 \mathrm{~kg}$ (Desember) dengan rata-rata $57 \pm 42$ (SD) kg.

Pada Gambar 4 terlihat bahwa di pantai Cilacap, standing biomass undur-undur laut gabungan tertinggi dijumpai pada bulan Februari sebesar $4.671 \mathrm{~kg}$, sedangkan terendah dijumpai pada bulan Maret sebesar $1.811 \mathrm{~kg}$. Berdasarkan jenis, standing biomass undurundur laut $E$. emeritus cenderung selalu lebih tinggi dari $H$. adactyla sebagaimana yang dijumpai di pantai Kebumen. Standing biomass E. emeritus di pantai Cilacap berkisar antara $1.462 \mathrm{~kg}$ (September) hingga $3.560 \mathrm{~kg}$ (Februari) dengan rata-rata $2.262 \pm 682$ (SD) kg, sedangkan untuk $H$. adactyla berkisar antara $234 \mathrm{~kg}$ (Maret) hingga $1.701 \mathrm{~kg}$ (Januari) dengan rata-rata $827 \pm 463$ (SD) kg.

Berdasarkan hasil di atas terlihat bahwa besaran standing biomass undur-undur laut famili Hippidae di pantai Cilacap lebih tinggi dari pantai Kebumen. Pada penelitian ini sebenarnya hanya ingin mendeskripsikan kondisi standing biomass undur-undur laut di masing-masing lokasi penelitian. Namun jika dibandingkan antarlokasi, berdasarkan hasil uji t $(P<0,05)$ menunjukkan bahwa besaran standing biomass undur-undur laut famili Hippidae di pantai Cilacap berbeda nyata dengan di pantai Kebumen. Kondisi ini dapat disebabkan oleh perbedaan kondisi lingkungan di masingmasing lokasi penelitian (Atar dan Secer 2003). Perbedaan waktu pengambilan sampel juga merupakan salah satu faktor yang dapat mempengaruhi perbedaan besaran biomasa dan juga standing biomass. Penelitian tentang biomassa dan/atau biomassa sesaat undur-undur laut belum pernah dilakukan di wilayah Indonesia, dan di dunia pun hanya pernah dilakukan di pantai Prainha, Brasil pada undurundur laut Emerita brasiliensis (Petracco et al. 2003).

Hasil penelitian Petracco et al. (2003) tersebut menyimpulkan bahwa perbedaan waktu dan musim pengambilan sampel undur-undur 
laut E. brasiliensis menghasilkan perbedaan besaran biomassa tahunan. Besaran biomassa tahunan undur-undur laut $E$. brasiliensis di pantai Prainha, Brasil, berbeda-beda berdasarkan musim pengambian sampel. Biomassa tahunan undur-undur laut $E$. brasiliensis tersebut pada

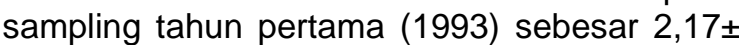
2,08 (SD) $\mathrm{gr} / \mathrm{m}^{2}$ pada jantan dan 2,74 $\pm 2,30$ (SD) $\mathrm{gr} / \mathrm{m}^{2}$ pada betina. Biomassa tahunan undur-undur laut $E$. brasiliensis tersebut kemudian meningkat pada sampling tahun kedua (1994) menjadi sebesar 12,35 $\pm 10,23(S D) \mathrm{gr} / \mathrm{m}^{2}$ pada jantan dan $10,74 \pm 9,55(\mathrm{SD}) \mathrm{gr} / \mathrm{m}^{2} \mathrm{pada}$ betina. Berdasarkan musim, biomassa undurundur laut $E$. brasiliensis musim panas selalu lebih tinggi dari tiga musim lainnya.

Berdasarkan jenis, undur-undur laut $E$. emeritus mempunyai standing biomass lebih besar dari Hippa adactyla di kedua lokasi penelitian. Hasil uji t $(\mathrm{P}<0,05)$ menunjukkan bahwa nilai standing biomass $E$. emeritus di pantai Cilacap dan Kebumen berbeda nyata dengan $H$. adactyla. Hasil penelitian ini makin menunjukkan dominasi undur-undur laut $E$. emeritus di lokasi penelitian secara khusus, dan secara umum di pantai selatan Jawa Tengah. Hasil penelitian Mashar et al. (2014) sebelumnya juga telah menunjukkan dominasi undur-undur laut $E$. emeritus atas jenis undur-undur laut lainnya secara populasi dan kelimpahan. Dominasi E. emeritus, baik secara populasi, kelimpahan, maupun standing biomass, dapat mengindikasikan bahwa pantai selatan Jawa Tengah merupakan habitat yang cocok bagi $E$. emeritus, baik ditinjau secara fisik (tipe pantai) maupun secara biologi (banyak sumber makanan).

Sepanjang pantai selatan Jawa Tengah mempunyai tipe pantai yang sama, yaitu tipe pantai dissipative, yang mempunyai karakteristik pantai bergelombang besar, bersubstrat pasir, dan mempunyai swash zone yang lebar (Wardiatno et al. 2014). Ketersediaan sumber makanan di perairan pantai tipe dissipative diduga relatif tinggi, baik yang bersumber laut sendiri dari hasil fotosintesis maupun dari perairan daratan, dimana banyak sungai yang bermuara di pantai selatan Jawa Tengah. Kondisi perairan pantai yang kaya sumber makanan sangat disukai oleh biota perairan, termasuk undur-undur laut, terutama genus Emerita. Hal tersebut sejalan dan mendukung hasil penelitian Celentano et al. (2010) yang menyebutkan bahwa pantai dengan tipe dissipative ini lebih disukai oleh undur-undur laut, terutama genus Emerita, dikarenakan ketersediaan sumber makanan di pantai tipe dissipative lebih tinggi dari pantai tipe reflective. Selain itu, dominasi $E$. emeritus di perairan pantai selatan Jawa Tengah juga makin mempertegas dan membuktikan hasil penelitian Boyko dan McLaughlin (2010) dan Haye et al. (2002) bahwa undur-undur laut genus Emerita banyak tersebar di pantai berpasir wilayah Asia Tenggara, dan pantai selatan Jawa Tengah adalah pantai berpasir yang berada di wilayah Asia Tenggara. Adapun untuk lokasi penelitian, ada faktor lain yang mempengaruhi perbedaan nilai standing biomass undur-undur laut di pantai Kebumen, yaitu luas pantai, terutama dipengaruhi oleh panjang pantai Kabupaten Kebumen yang lebih pendek dari Kabupaten Cilacap dan tingginya aktivitas wisata pantai di sebagian besar pantai di Kabupaten Kebumen. Sedangkan pantai Cilacap, selain lebih panjang dari pantai Kebumen, kuantitas dan intensitas aktivitas manusia di sebagian besar pantai Cilacap, diantaranya kegiatan wisata pantai, tidak setinggi di pantai Kebumen.

Aktivitas wisata pantai di pantai-pantai berpasir Kabupaten Kebumen sebagian besar dilakukan di daerah intertidal yang merupakan habitat undur-undur laut famili Hippidae. Kondisi tersebut secara langsung mengganggu keberadaan undur-undur laut di pantai tersebut karena habitat hidup mereka terganggu. Akibatnya secara alamiah undur-undur laut akan mencari pantai-pantai berpasir lainnya yang belum terganggu oleh aktivitas manusia. Dampaknya adalah populasi undur-undur laut yang bertahan di pantai tersebut semakin sedikit dan semakin menurun, sehingga secara umum mempengaruhi rendahnya kelimpahan dan selanjutnya mempengaruhi rendahnya besaran standing biomass undur-undur laut di pantai Kebumen.

Hasil penelitian ini juga menunjukkan bahwa undur-undur laut famili Hippidae mempunyai peluang dan potensi yang cukup terbuka untuk dapat menjadi salah satu alternatif sumber pangan. Disamping karena undurundur laut mempunyai potensi menyumbang biomassa, juga karena kandungan gizi undurundur laut juga sangat tinggi, seperti protein, lemak, omega-3, dan omega-6 (Mursyidin 2007; Hartono et al. 2011; Santoso et al. 2015). Undur-undur laut dapat menjadi salah satu sumber protein hewani bagi masyarakat, terutama untuk anak-anak yang masih dalam masa pertumbuhan, karena secara ekonomi harga undur-undur laut masih terjangkau oleh masyarakat.

Dari sudut pandang sektor perikanan, hasil penelitian menunjukkan adanya potensi ekonomi yang cukup menjanjikan bagi masyarakat pesisir di sekitar lokasi penelitian, terutama bagi nelayan pencari undur-undur laut. Apabila rata-rata standing biomass undur-undur laut famili Hippidae di pantai berpasir Kebumen 
adalah sebesar $286 \mathrm{~kg}$ dan pantai berpasir Cilacap adalah sebesar $3.225 \mathrm{~kg}$, serta harga rata-rata undur-undur laut berdasarkan hasil wawancara dengan nelayan undur-undur laut adalah sekitar Rp 20.000,- per kg, maka terdapat potensi ekonomi yang bisa diraih dari undur-undur laut diperkirakan sebesar $\mathrm{Rp}$ 5.72.000,- di Kabupaten Kebumen, dan sebesar Rp 64.500.000,- di Kabupaten Cilacap untuk setiap aktivitas penangkapan undurundur laut di sepanjang pantai kedua kabupaten tersebut. Potensi nilai ekonomi undur-undur laut tersebut, lepas dari besar atau kecilnya, tentu sangat bermanfaat bagi masyarakat, terutama bagi mereka yang menjadi nelayan undur-undur laut. Namun jauh yang lebih penting adalah mempertahankan keberadaan dan kelestarian sumber daya undur-undur laut di wilayah tersebut, agar peran dan manfaatnya dapat terus berlanjut, baik secara ekologi maupun ekonomi. Oleh karena itu, pengelolaan sumber daya undur- undur laut tersebut secara bijak dengan memperhatikan peran ekologi dan ekonominya harus sudah mulai dipikirkan oleh pemerintah, terutama pemerintah daerah. Secara konsep, teknis, maupun kelembagaan, pemerintah daerah dapat menjalin kerjasama dengan perguruan tinggi, masyarakat pesisir, terutama nelayan undur-undur laut, dan pengelola wisata pantai. Rumusan pengelolaan sumber daya undur-undur laut tersebut harus mulai dirancang dari sekarang agar tidak terjadi over exploited undur-undur laut dan potensi pantai berpasir untuk manfaat lain juga tetap bisa optimal. Dengan demikian diharapkan dapat diwujudkan kelestarian dan keberlanjutan peran dan fungsi sumber daya undur-undur laut, baik secara ekologi maupun ekonomi. Populasi dan biomassa undur-undur laut tetap seimbang di ekosistemnya dalam menjalankan perannya secara ekologi, dan masyarakat masih bisa memanfaatkan secara terbatas dan bijak untuk memenuhi kebutuhan ekonominya.

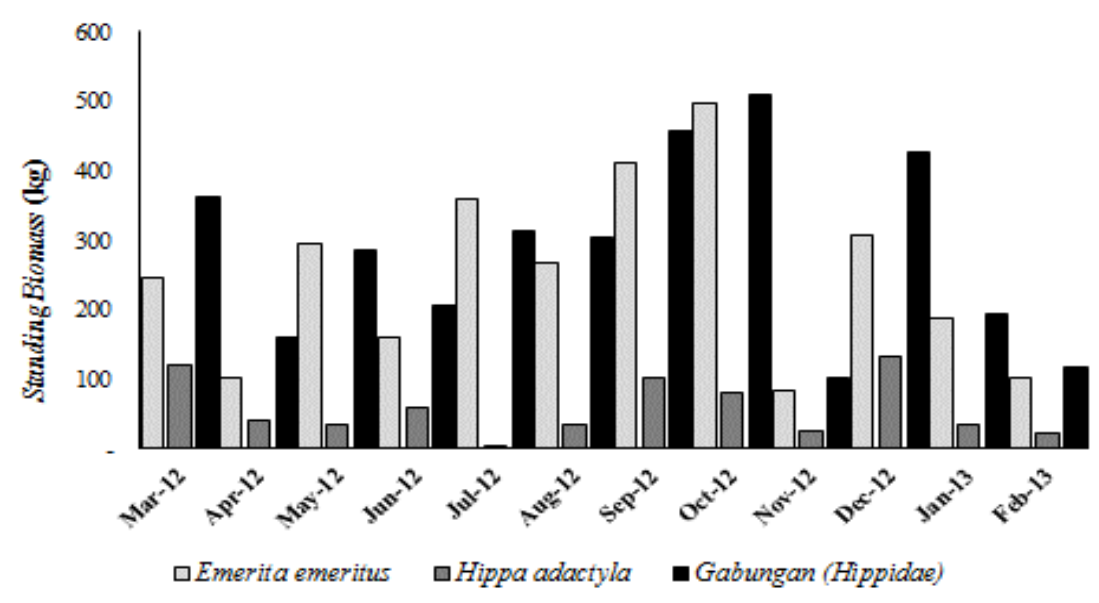

Gambar 3 Dinamika standing biomass undur-undur laut famili Hippidae di pantai berpasir Kabupaten Kebumen

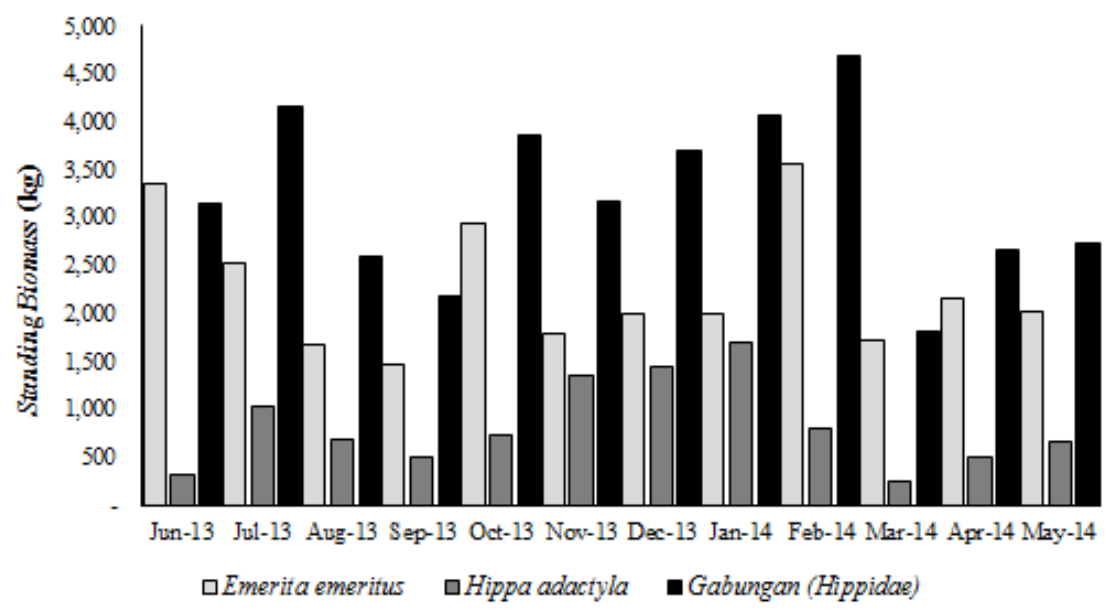

Gambar 4 Dinamika standing biomass undur-undur laut famili Hippidae di pantai berpasir Kabupaten Cilacap 


\section{KESIMPULAN}

Undur-undur laut famili Hippidae, Emerita emeritus dan Hippa adactyla, di pantai berpasir Kabupaten Kebumen dan Kabupaten Cilacap mempunyai biomassa sesaat atau standing biomass yang besarannya berbeda dan fluktuatif. Perbedaan besaran standing biomass undur-undur laut dipengaruhi oleh ketersediaan sumber makanan dan kondisi lingkungan pantai. Secara umum, besaran standing biomass undur-undur laut $E$. emeritus lebih tinggi dari $H$. adactyla di pantai selatan Jawa Tengah.

\section{SARAN}

Untuk mendapatkan hasil perhitungan biomassa sesaat atau standing biomass sumber daya undur-undur laut dengan tingkat akurasi lebih tinggi, maka dalam penangkapan sampel undur-undur laut perlu dirancang alat tangkap undur-undur laut yang standard, bukan alat bantu deteksi undur-undur laut, dan dapat dioperasikan oleh siapa pun. Perlu kajian status pemanfaatan undur-undur laut untuk mengetahui sejauh mana undur-undur laut masih boleh dimanfaatkan atau dieksploitasi, baik secara kuantitas maupun waktu.

\section{DAFTAR PUSTAKA}

Atar HH, Secer S. 2003. Width/Length-Weight Relationships of the Blue Crab (Callinectes sapidus Rathbun 1896) Population Living in Beymelek Lagoon Lake. Turk J Vet Anim Sci. 27: 443-447.

Boyko CB. 2002. A Worldwide Revision of the Recent and Fossil Sand Crabs of the Albuneidae Stimpson and Blepharipodidae, New Family (Crustacea: Decapoda: AnoMura: Hippoidea). Bulletin of the American Museum of Natural History. 272: 1-121.

Boyko CB, Harvey AW. 1999. Crustacea Decapoda: Albuneidae and Hippidae of the Tropical Indo-West Pacific Region, in Crosnier A. (ed.), Résultats des Campagnes MUSORSTOM. Volume 20. Mémoires du Muséum national d'Histoire naturelle. 180: 379-406.

Boyko CB, Mclaughlin PA. 2010. Annotated Checklist of Anomuran Decapod Crustaceans of the World (Exclusive of the Kiwaoidea and Families Chirostylidae and Galatheidae of the Galatheoidea) The Raffles Bull of Zoology. 23: 139-151.
Celentano E, Gutierrez NL, Defeo O. 2010. Effect of Morphodynamic and Estuarine Gradients on the Demography and Distribution of Sandy Beach Mole Crab: Implications of Source-Sink Habitat Dynamics. Mar Ecol Prog Ser 398: 193205.

Efford IE. 1976. Distribution of the Sand Crabs in the Genus Emerita (Decapoda, Hippidae). Crustaceana. 30: 169-183.

Haley SR. 1982. Zonation by Size of the Pacific Mole Crab, Hippa pacifica Dana (Crustacea: Anomura: Hippidae), in Hawaii. JExp Mar Biol Ecol. 58: 221-231.

Hartono E, Rejeki ES, Puspitasari AA. 2011. Pengaruh Asupan Makanan UndurUndur Laut terhadap Kandungan Omega 3 pada Telur Itik. J Biomedika 4: 60-65.

Haye PA, Tam YK, Kornfield I. 2002. Molecular Phylogenetics of Mole Crabs (Hippidae: Emerita). Journal of Crustacean Biology. 22(4): 903-915.

Mashar A, Wardiatno Y. 2013a. Aspek Pertumbuhan Undur-Undur Laut Emerita emeritus dari Pantai Berpasir Kabupaten Kebumen. Jurnal Biologi Tropis. 13(1):2938.

Mashar A, Wardiatno Y. 2013b. Aspek Pertumbuhan Undur-Undur Laut, Hippa adactyla dari Pantai Berpasir Kabupaten Kebumen. Jurnal Biologi Tropis. 13(2): 119-127.

Mashar A, Wardiatno Y, Boer M, Butet NA, Farallah A. 2014. Diversitas dan Kelimpahan Kepiting Pasir di Pantai Selatan Jawa Tengah. IImu Kelautan. 9(4): 226-232.

Mursyidin DH. 2007. Kandungan Asam Lemak Omega 6 pada Ketam Pasir (Emerita spp.) di Pantai Selatan Yogyakarta. Bioscientiae. 4(2): 79-84.

Osawa M, Boyko CB,Chan TY. 2010. [Part I. Hippoidea (Mole Crabs)]. In: [Crustacean fauna of Taiwan: Crab-Like Anomurans (Hippoidea, Lithodoidea, Porcellanidae)]. Chan TY (ed), Institute of Marine Biology, Taiwan, pp. 1-40.

Petracco M, Veloso VG, Cardoso RS. 2003. Population Dynamics and Secondary Production of Emerita brasiliensis (Crustacea: Hippidae) at Prainha Beach, Brazil. P.S.Z.N.: Marine Ecology. 24(3): 231245.

Santoso J, Hanifa YN, Indariani S, Wardiatno Y, Mashar A. 2015. Nutritional Values of the 
Indonesian Mole Crab, Emerita emeritus: are They Affected by Processing Methods?. AACL Bioflux. 8(4): 579-587.

Siegel PR, Wenner AM. 1984. Field and Laboratory Studies of Sand Crab Growth. In: Wenner AM (ed.) Crustacean Growth, Crustacean Issues. Vol II. Rotterdam: Balkema Press.

Wardiatno Y, Nurjaya IW, Mashar A. 2014. Karakteristik Habitat Undur-Undur Laut
(Famili Hippidae) di Pantai Berpasir, Kabupaten Cilacap. Jurnal Biologi Tropis. 14(1): 1-8.

Wardiatno Y, Ardika PU, Farajallah A, Butet NA, Mashar A, Kamal MM, Renjaan EA, Sarong MA. 2015. Biodiversity of Indonesian Sand Crabs (Crustacea, Anomura, Hippidae) and Assessment of Their Phylogenetic Relationships. AACL Bioflux. 8(2): 224-23. 